\title{
腰部脊柱管狭窄症に対する拡大開空術の治療成績
}

\author{
鹿児島大学整形外科 \\ 今 村 健 志・酒 匂崇 \\ 米和 徳
}

\section{Clinical Study of Fenestration for Lumbar Canal Stenosis}

by

\author{
Takeshi Imamura, Takashi Sakou \\ and Kazunori Yone
}

Department of Orthopedic Surgery, Faculty of Medicine, Kagoshima, University, Japan

We performed fenestration on 22 patients with lumbar canal stenosis.

The average follow-up period was 18 months, ranging from 6 to 41 months.

We evaluated the postoperative results according to the criteria for lumbar disorder of the Japanese Orthopaedic Association ( JOA score).

The average preoperative JOA score was 13 . After operation, symptoms were reduced in many patients, with an average JOA score of 22.8 and an improvement rate of $55 \%$.

Fenestration is a useful procedure for degenerative and combined type of lumbar canal stenosis.

\section{はじめに}

従来, 我々は腰部脊柱管狭窄症（以下 LCS）に対し て広範椎弓切除術を行ってきた。しかし, 最近, 症例 によっては画像所見や臨床所見を参考にして，より侵 襲の少ない拡大開空術を施行している. 今回, 短期で はあるがその術後成績を検討し，手術適応，手術方法 の選択について考察したので報告する.

\section{対象および方法}

1987 年以降，我々は，国際分類”による degenerative type や combined type で高度の沪りを呈しない ものに対して，主に拡大開空術を選択している.

今回, 当科にて拡大開空術を施行し, 術後 6 力月以 上経過した LCS のうち, follow up の可能であった 22 例を対象とした。性別は男性 13 例, 女性 9 例, 手術時 年齢は 39 歳より 79 歳で平均 62.2 歳, 術後経過観察期 間は 6 月から 3 年 5 力月で平均 1 年 6 力月である。

神経障害形式による分類では, 馬尾型 8 例, 神経根
型 3 例, 混合型 11 例であった。

手術範囲は 1 椎間 7 例, 2 椎間 9 例, 3 椎間 6 例で, 椎間板摘出を併用したものが 10 例 10 椎間あった.

これらの症例に対して, 日本整形外科学会が定めた 腰痛治痛成績判定基準, 以下 (JOA score) と疼痛の 程度, 仕事への復帰, 活動の制限, 鎮痛剤の使用を考 慮しStauffer の判定基準を用いて臨床成績を評価し た.

\section{結果}

JOA score は, 総合点で術前点数, $4 \sim 23$, 平均 13 点が, 術後, 17〜29, 平均 22.8 点わで改善した.

Stauffer の判定基準では Good が $27 \%$, Fair が 64 \%, Poor が $9 \%$ あっった。

症状別にみると, 特に間欠性跛行の改善は著しく, 下肢痛も良く改善していた。しかし，腰痛は消失した ものが 8 例あったが, 不変のものも 5 例見られた（図 $1)$. 


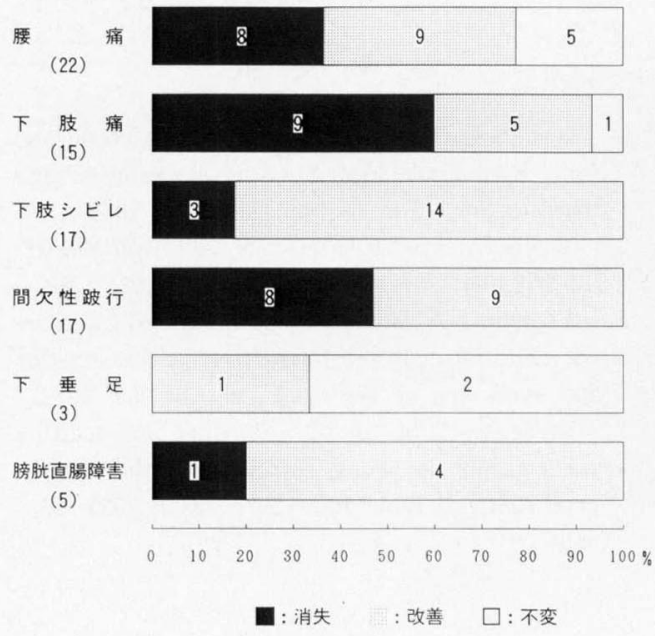

図 1 術後の症状の改善

症例

69 歳, 女性. 主訴は腰痛, 左下肢痛及び下垂足であ る.

Myelogram では, 正面像で L 4/5 間, L 5/S 1 間で 神経根のう像の欠損が圧排を認める. 側面像では L 2/ 3 間, L $3 / 4$ 間, L 4/5 間, L 5/S 1 間で前方および後方 からのミエロ柱の圧排所見を認めた（図 2 ).

CT-Myelogram では, L 3/4 間, L 4/5 間, L 5/S 1 間で両側の lateral recessの狭小化を認め, ミエロリ ングは圧排されて変形している(図 3 )。

L 3/間, L 4/5, L 5/S 1 間の拡大開空術を施行した. 術前あった腰痛, 下肢痛は消失し, 下肢のシビレも軽

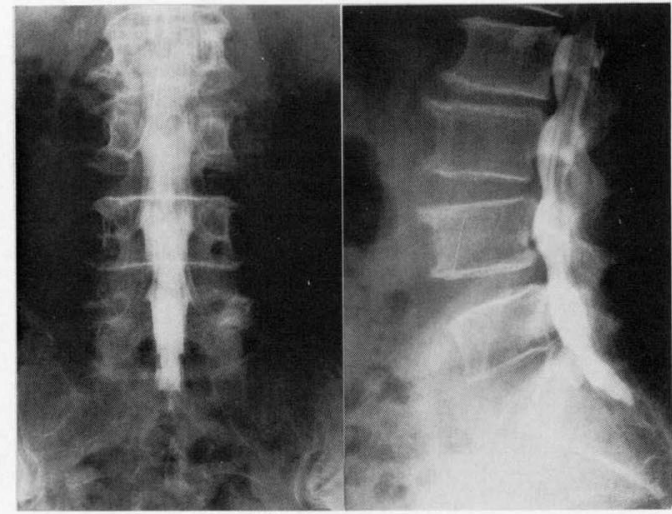

図 2 yelogram

正面像で L $4 / 5$ 間, L $5 / \mathrm{S} 1$ 間で神経根のう像の欠 損や圧排を認める.

側面像では L 2/3,L $3 / 4, L$ 4/5 間, L 5/S 1 間で 益方および後方からミエロ柱の圧排を認めた.

快した。下腿の筋力低下も改善した. JOA score は術 前 8 点や術後 1 年 2 力月の調査時には 28 点と著明に 改善した.

\section{考察およびまとめ}

我々はLCSの手術術式において, degenerative type や combined type で高度の过りを呈しないもの に対しては拡大開空術を, congenital type に対しては 椎弓切除術を施行し, また, 分離之り, 高度の変性过 り, 若年, 壮年で不安定椎を有するもの, post operativeのものには除圧術に加えて instrumentation を併 用した固定術を行なっている.

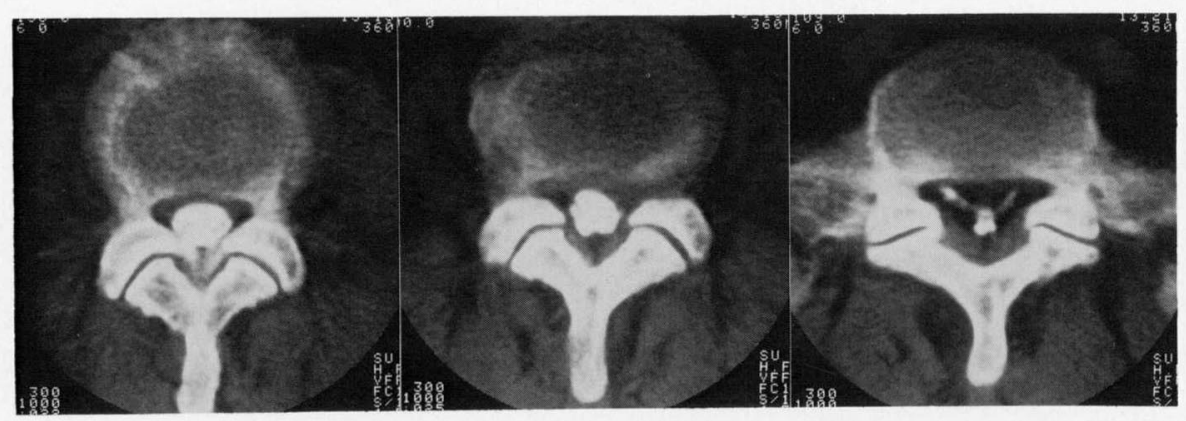

図3 CTM

L 3/4 間，L 4/5 間，L 5/S 1 間で両側の lateral recess の狭小化を認め，ミエロリングは 圧排され変形している. 
拡大開空術の手術成績は JOA score で改善率 $55 \%$ と以前行なっていた椎弓切除術とほほ同様な成績であ った2). 特に間欠性跛行や下肢痛は著しく改善した. LCS の退行性変性による神経組織の圧迫因子は, 椎間 板, 椎間関節および黄色勒帯である ${ }^{3) 4}$.これらは interarticular segment に存在しており, 術前の臨床症状や 画像診断などを参考にして障害部位を的確に判断すれ ば除圧効果は十分と考えている。

しかし，成績不良例では，腰痛が残存したものが多 く,これらの多くは術前不安定椎の存在をみるも, 高 龄者であったため, 固定術を併用しなかった症例であ った. 最近，このような症例に固定術の併用を試み, 良好な成績を得ている。

LCS の手術療法としては, 除圧には拡大開空術を行
い,必要に応じて固定術を併用すべきであると考える。

\section{参考文 献}

1) Arnoldi, C. C., et al. : Lumbar Spinal Stenosis and Nerve Root Entrapment Syndromes. Definition and Classification. Clin. Orthop., 115:4-5, 1976.

2 ）森園良幸, ほか：腰部脊柱管狭窄症の術後成績不良 例の検討. 西日本脊椎研究会誌, $14: 98-102,1988$.

3 ) Epstein, J A., et al. : Sciatica caused by nerve root entrapment in the lateral recess; the superior facet syndrome. J. Neursurg., $36: 584-589,1972$.

4) Getty, C. J. M., et al. : Partinal undercutting facete ctomy for bony entrapent of the Iumbar nerve root. J. Bone Joint Surg., 68-B : 330-335, 1981. 